\title{
Development of Labor Resources in the "Transportation and storage" Sector of Bulgaria
}

\author{
Donka Zhelyazkova \\ d_zhelyazkova@ue-varna.bg
}

\begin{abstract}
Labor resources are an important factor in the development of each sector of the national economy. Theoretically, the focus of attention is on the workforce considered in the context of factors influencing decisions related to the location of economic activities. Of particular interest in the present work are persons employed under the employment relationship in the "Transportation and storage" sector of Bulgaria, who are both hired in land, air and water transport, as well as in the activities of warehousing and cargo handling, support activities in transport and in postal and courier services. The research part analyzes the dynamics of the development of employees in the "Transportation and storage" sector of Bulgaria during the period 2002 - 2018. Finally, key conclusions are drawn regarding the development of labor resources in the sector.
\end{abstract}

Keywords: transport, storage, labor resources.

JEL Code: R4, E2; doi:10.36997/IJUSV-ESS/2019.8.3.3

\section{Introduction}

The development of labor resources is a problem with an emphasized actuality, defined by the influence which this process has on the economic and social security in the state. The importance of the labor potential of an economy defines to a substantial degree its attractiveness for potential investors as well, who take into account the quantitative parameters, as well as the indicators, measuring the productivity of labor.

The aim of this elaboration is to reveal some theoretic formulations, related to labor resources and based on an analysis of hired persons development in the "Transportation and storage" sector in Bulgaria, to formulate fundamental conclusions in the outlined direction.

For the achievement of the so formulated aim, three basic tasks can be deduced:

1. Theoretical formulations to be reviewed, connected with labor resources.

2. The dynamics of the development to be analyzed, of the hired persons in the "Transportation and storage" sector in Bulgaria in the period $2002-2018$.

3. Conclusions to be formulated regarding labor resources development in the "Transportation and storage" sector in Bulgaria during the period of research.

\section{Theoretical formulations, connected with labor resources}

An important point at the examining of labor resources as a whole is their role for the transformation of an economy in an attractive center for companies with stable market positions, which look for opportunities for expansion or dislocation of their business. According to Rodrigue (Rodrigue, 2013) labor resources are situated at the second level in the basic factors pyramid, having an influence on the decisions, related to the locating of economic activities (see fig. 1).

At the base of this pyramid at a macro (national) level, the author places socio-economic factors such as capital, subsidies, regulations, taxation, technologies. The second meso- (regional) level includes accessibility of labor and material resources, energy, markets, suppliers/customers. At the top of the pyramid are the factors at a micro or local level, which are land, communal services, transparency, transportation (local access) and conveniences.

In the context of this theory, systemizing the factors, which have influence during the choice of localization of the business processes we notice, that labor resources take one of the important places and this determines the necessity of focusing of the attention on their special features and the dynamics of their development within the range of the separate economic sectors.

In the theory, the labor resources of an enterprise consist of all categories of employees, who 
are hired by the enterprise. In its personnel different job positions can be included, starting from the highest management and reaching to ordinary employees and workers. (Ganchev, 2013). Concretely in transport these are human resources with versatile professional and qualification structure, in view of the character of the performed activities - transportation, loading-unloading, maneuvering, repair works, commercial, etc. (Grukhlanska, 2014).

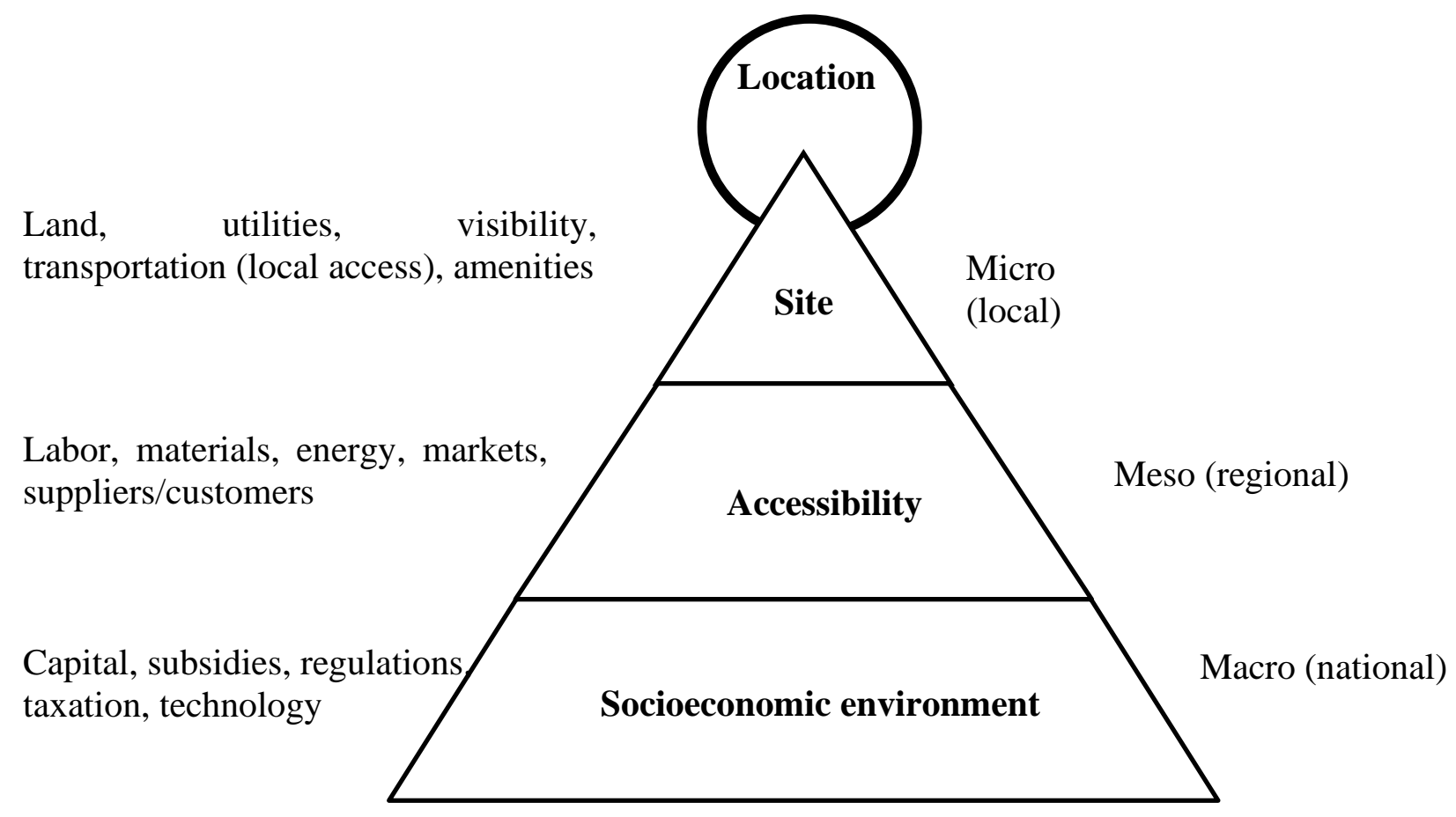

Figure 1. Basic location factors.

Specifics are observed, in relation to the requirements to the professional skills of the persons engaged in the different types of transport, dictated by the peculiarities of the characteristics of labor positions, in connection with the management of the mobile staff, as well as its maintenance. This practically means, that the hired persons in the sector are differentiated according to the type of transport and by definition (NSI, 2019) these are the persons who are in a labor relation with the employer, according to the Labor code (Kodeks na truda, 2018), i.e. these are relations, at which a salary is given (within the meaning of art. 1, par. 2), or in a business relation, which originates based on an administrative act, in compliance with art.9, par. 1 from the State employee act (Zakon za durzhavniya sluzhitel, 2019), by virtue of which relations they receive a compensation in money or in kind in the form of labor wages for a performed in a definite volume and quality work, independently if the contract for hiring is ongoing or temporary, at a full or parttime.

Additionally, the hired persons who are in a labor relation with the employer, can be viewed as permanently or temporarily hired. The permanently hired staff functions all year long with minor changes, caused by the natural personnel fluctuation (leaving because of dissatisfaction, completed years for retirement, etc.). The temporarily hired staff is attracted to the enterprise for a definite time period - hours from the work shift, days of the week or month, season of the year, etc. (Blagoev, Bl. et al., 2010).

In the present elaboration, a concrete interest constitute the hired under a labor relation persons in the "Transportation and storage" sector, who are the hired in land, air and water transport, as well as in the activities of warehousing and cargo processing, subsidiary activities in transport and in postal and courier services. 
2. Analysis of the hired persons' dynamics in the "Transportation and storage" sector of Bulgaria in the period $2002-2018$

The analysis of the dynamics in the development of the indicators of the structure of the hired persons under a labor or business relation in the "Transportation and storage" sector for the period $2002-2018$, reveals tendencies of decrease in the relative share of the hired in water transport and a growth of the employed in land transport as a whole (see table 1). The data from the table outline a smooth, but constant increase of the interest in land alternatives from the side of the active population and this is an indication of its operating activity, causing a necessity of hiring of work force. In the year 2002 the hired persons in the land transport variants were 55,573\% from the total number of hired persons in the sector, and in 2018 they are already 62,662\% (see fig. 2 and 3).

With an opposite movement direction are the fluctuations in water transport for these indicators, where a reduction of the available staff is reported. By analogy, the association which causes this fact, is connected with a decrease of the report data of the indicators for transported cargoes and work performed in this transportation segment, as a result of diminished commercial exchange between Bulgaria and partners, operating at remote markets.

No substantial deviations are observed in the remaining activities, from the average relative shares, which is an attest for stability in relation to the engaged personnel and its economic activity. The decrease is $0,557 \%$ in air transport in 2018 with a basis the year 2002 . In postal and courier services the decrease of the relative share is even smaller and amounts to $0,138 \%$ for the same time range. Just in activities of warehousing and cargo processing, the subsidiary transport activities, a decrease of the relative shares is determined during that period at the amount of $1,547 \%$.

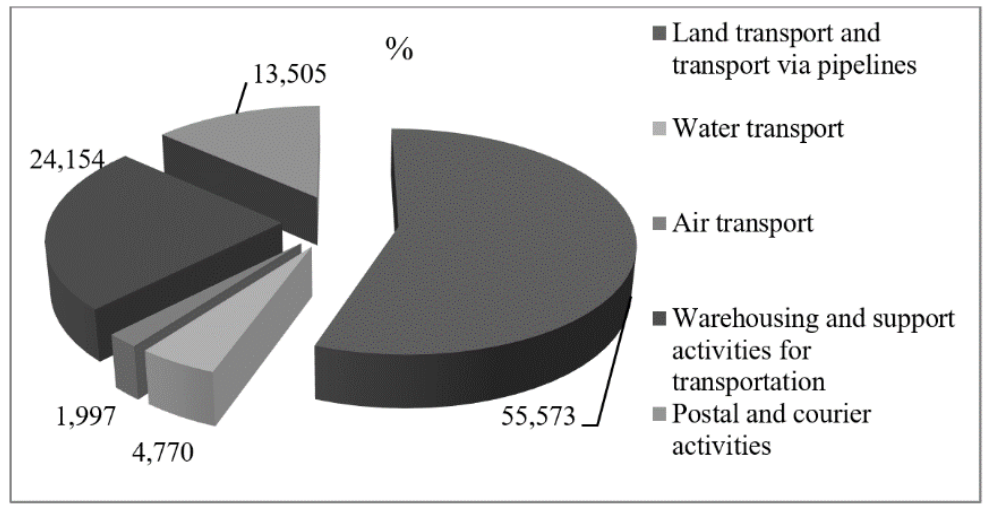

Source: NSI.

Figure 2. Structure of the hired persons in year 2002 in the "Transportation and storage" sector.

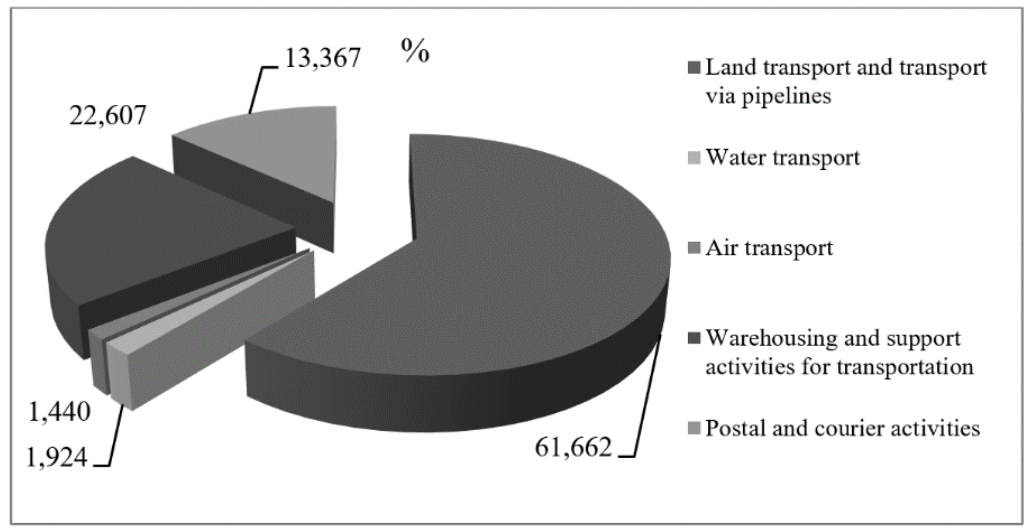

Source: NSI.

Figure 3. Structure of the hired persons in year 2018 in the "Transportation and storage" sector. 
Table 1. Dynamics of the relative shares of employed persons under a labor or business relation by basic types of transport in "Transportation and storage" sector for the period $2002-2018$.

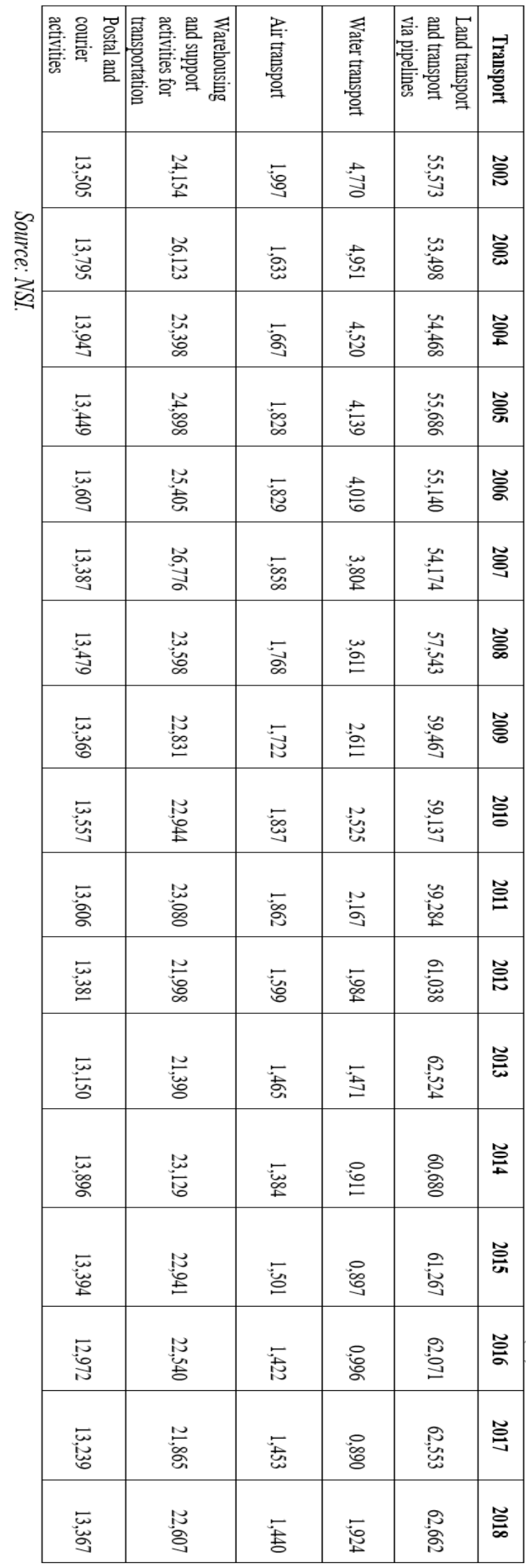


In order to configure with a bigger specifics the actual state of labor resources in the sector, the number of hired persons and their labor productivity have to be compared from a dynamic angle, defined through the interrelation of the production made and the input quantity for its production (Bakalova, V., Khr. Nikolova, 2010). Taking into consideration the established interest in land transport and the determined decrease of water transportation, we shall trace the development of these indicators throughout the years, reported by both transport alternatives. The aim of this survey will be to observe the movement during the years of the deduced interdependence between the two indicators.

In figure 4 the dynamics in the development of the hired persons is outlined, as well as the labor productivity in land transport of Bulgaria for the period $2002-2018$. We notice, that the two curves draw an ascending development trend, which is characterized by a certain instability during the crisis for each economy $2008-2009$.

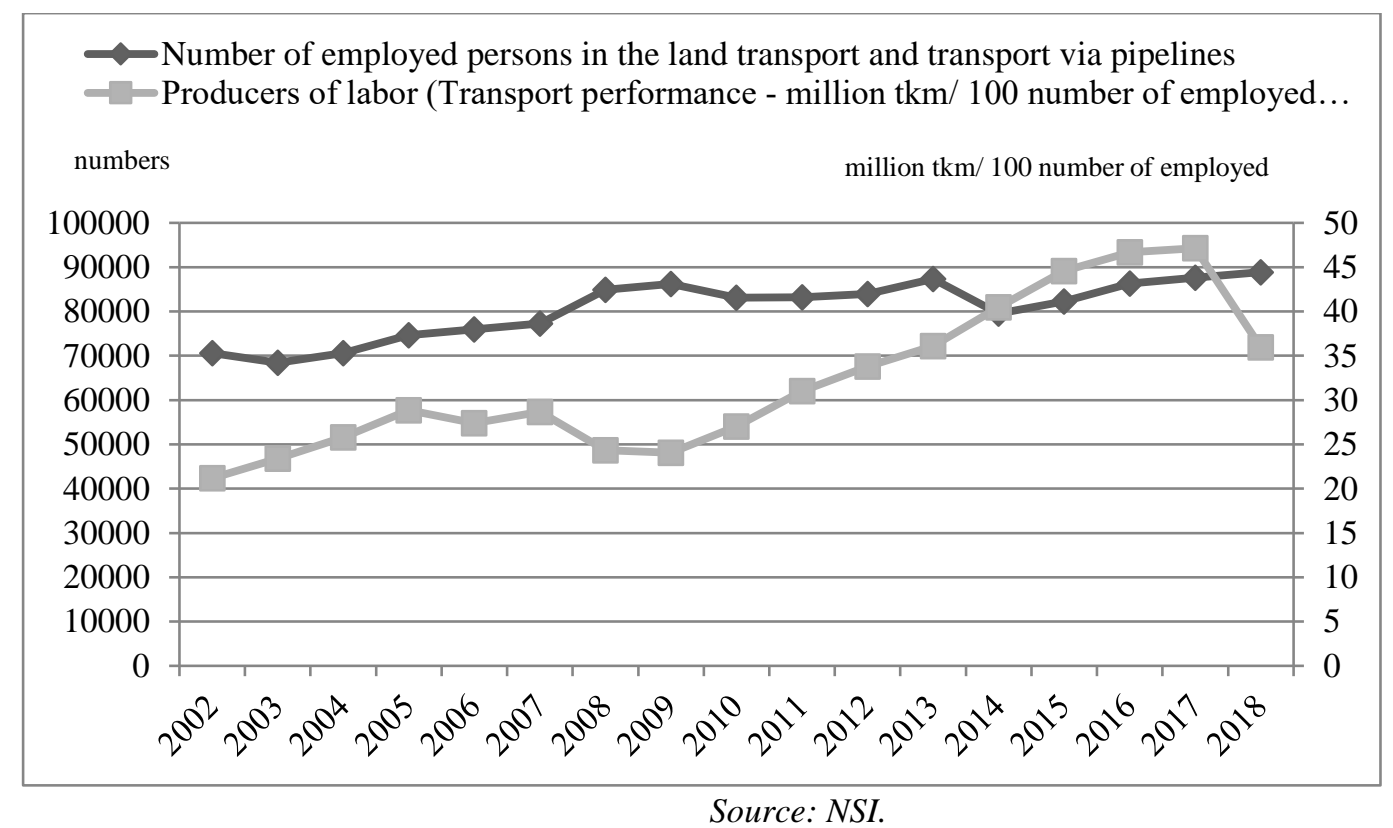

Figure 4. Dynamics in the development of hired persons and labor productivity in the land transport of Bulgaria in the period $2002-2018$.

In the course of the analysis we have to underline the fact, that during a substantial part of the chosen time range, the number of the hired persons outdistances the productivity of labor, which from an economic point of view is unfavorable for the companies operating in the sector. This is an indication about a certain extensiveness during the performing of business activities, as the results are increased, measured on grounds of performed work and hired persons, but with slower speed in relation to the growth of the human factor, engaged in the sector. From year 2009 till 2017 the labor productivity grows, which shows, that the labor resources increase their efficiency, as they transport bigger volumes at longer distances, measured by 100 people hired personnel in the land transportation sector. During one single year, the trend reverses and a decrease of the labor productivity is reported, at a slight increase of the number of hired persons, which could be due to different factors, the most important of which can be connected with the expectations for the sector development, with changes in the normative regulation, etc.

A contrast to the tendencies, reported in the development of land transport, are the actual dimensions in the water transport segment. In figure 5 we visualize the dynamics in the development of the hired persons and the labor productivity in the water transport of Bulgaria for the period $2002-2018$. 


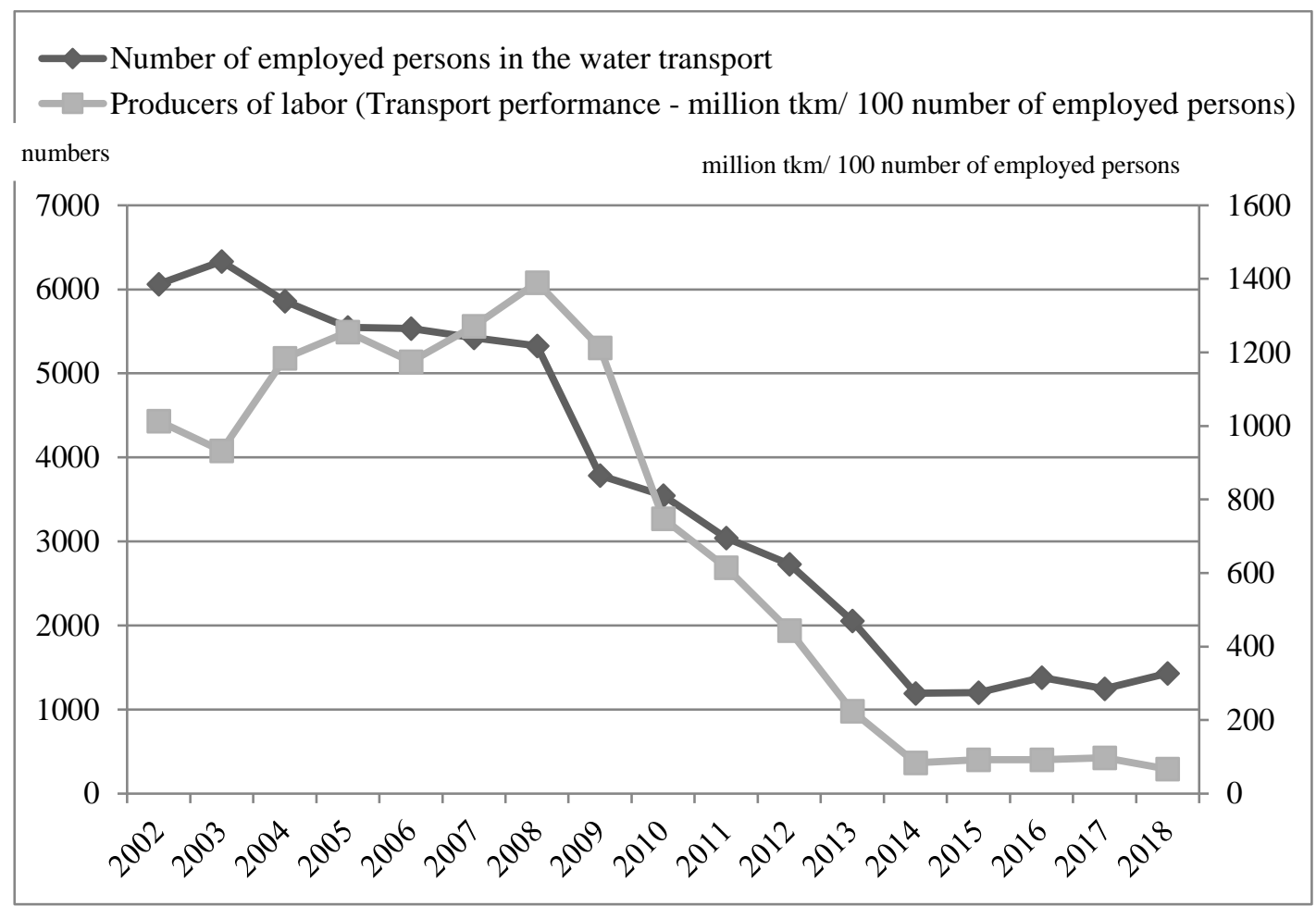

Source: NSI.

Figure 5. Dynamics in the development of hired persons and labor productivity in the water transport of Bulgaria for the period $2002-2018$.

The decrease under the two researched indicators is categorical, as during the last years from the period the number of hired persons decreases with 4629 persons or in a relative share this amounts to $-76,372 \%$. Respectively, the productivity of labor reports levels of 1012,869 million tkm per 100 people of hired staff in 2002 and 66,670 million tkm per 100 people of hired staff in 2018, or the decrease is over fifteen times within 17 years. The facts are an evidence of an extremely slowed down rhythm of work in the water transport.

\section{Conclusions about the labor resource development in the "Transportation and storage" sector in Bulgaria}

On grounds of the performed analysis the following main conclusions can be made:

1. The structure of the hired persons under a labor and business relation in the „Transportation and storage" sector for the period 2002 - 2018 changes its parameters during the years, mainly influenced by reported miscellaneous dynamics in the development of the relative shares in the land and water transport. The increase of the relative share of employed persons in land transport, can be attributed to the priority development of road transports, in view of the fact that no changes are observed in a positive direction, regarding the indicators measuring transported cargoes and work performed by the Bulgarian railways, as well as a lack of new projects, which to contribute for a growth in the sector of pipeline transport.

On the other hand, the crisis in water transport is getting deeper, which is confirmed by the fact, that Bulgaria is excluded as a trade flag owner from all the lists of the Paris memorandum - an organization of all European and a part of the world maritime countries, regarding the port control of ships (Transportal, 2019).

2. The land transport develops in a positive direction regarding the studied indicators, giving an account of the number of hired persons and their labor productivity, but in the last 2018 year, a decrease is observed regarding productivity indicators, dictated by the slight increase of the absolute number of employees and the reduction of work performed. 
3. A crisis situation is observed in the water transport, outlined by the curves of the number of hired persons and productivity of labor, as the most serious are the indications for the availability of problems of strategic importance after the year 2008. The main reasons for the emerged situation are connected with the decreased number of vessels, which kept the Bulgarian flag, which according to data of the National Institute of Statistics as of year 2002 (NSI, 2006) amounted to 86 sea cargo ships with a full loading capacity of 1615,317 thousand tons, and 167 river not selfpropelled cargo ships with a loading capacity of over 249 thousand tons. As of 2018 the number of sea vessels for cargo transportation drops to 3 with 12 thousand tons deadweight, and the river not self-propelled vessels amount to 111 with 187 thousand tons loading capacity. The reorientation to foreign shipping registers is dictated by the more strict regulations over the technical and administrative aspects of the ship operation, as well as the usually higher tolls, in comparison with countries like Panama, Liberia, the Bahamas, Malta, Cyprus, the Bermuda, etc.

\section{Conclusion}

The attractiveness of the "Transportation and storage" sector for investors, is in a direct dependence on the quantitative parameters of labor resources, which are at the market's disposal, and on the measuring of their productivity of labor. In Bulgaria, the highest relative share of hired persons under a labor contract is registered in the land types of transportation (automobile, railway and pipeline), who accumulate over $60 \%$, and the least number of employees is reported in aviation, with levels under $2 \%$. The productivity of labor reports analogous parameters.

There is no reason to expect in the future a cardinal change of the outlined directions, in view of the lack of investment interest in the revival of Bulgarian ports and the railways, and of the growing interest in road transports, dictated mainly by the high cost of air transportation and by the economic interests of the market agents, connected with the limited volumes of traveling material currents, and the comparatively short distances between the initial and end points of motion.

\section{References}

1. Bakalova, V., Khr. Nikolova (2010) Ikonomika na transporta, Sofiya: Universitetsko izdatelstvo „Stopanstvo“, s. 152.

2. Blagoev, Bl. et al. (2010) Ikonomika na predpriyatieto. Varna: Nauka i ikonomika, s. 171.

3. Grukhlanska, Tsv. (2014) Upravlenie na kachestvoto na truda v transportnoto predpriyatie. // Mekhanika, Transport, Komunikatsii, tom 3, br. 1, s. III-22.

4. Ganchev, M. (2013) Izpolzvane na sistemniya podkhod pri izsledvaneto na ikonomicheskiya potentsial na industrialno predpriyatie. // Nauchni trudove na Rusenskiya universitet, tom 52, seriya 5.1, s. 254.

5. Kodeks na truda (2018) // V sila ot 01.01.1987 g., izm. i dop. DV. br. 92 ot 6 Noemvri 2018 g. Dostupen na: <https://lex.bg/bg/laws/ldoc/1594373121> (18.08.2019).

6. NSI (2019) Metadanni i metodologiya. Dostupen na: <http://www.nsi.bg/bg/content/992/naetilitsa> (12.08.2019).

7. NSI (2019) Statisticheski godishnik 2006, Sofiya. Dostupen na: <http://istmat.info/files/uploads/51343/statisticheski_godishnik_2006.pdf> (20.08.2019).

8. Rodrigue, Jean-Paul (2013) The Geography of Transport Systems, London and New York: Routledge, p. 73.

9. Transportal (2019) Izklyuchikha bulgarskiya morski flag ot vsichki spisutsi na Parizhkiya memorandum. Dostupen na: <https://transportal.bg/izklyuchikha-bŭlgarskiya-morski-flag-otv/?fbclid=IwAR3ZYQfqR31cqVU4ptDfFM4pe7yKpLnAe_YMwpCRT_upKVMtatKuU45qWs> (18.08.2019).

10. Zakon za durzhavniya sluzhitel (2019) // V sila ot 27.08.1999 g., izm. DV. br. 23 ot 19 Mart 2019 g. Dostupen na: <https://lex.bg/bg/laws/ldoc/2134673408> (18.08.2019). 